\title{
VULVAR LIPOMA IN POSTMENOPAUSAL LADY: A RARE CASE REPORT
}

Jayanta Ray ${ }^{1}$, Abhijit Datta루, Ashis Kumar Rakshit ${ }^{3}$, Salil Bindu Chakraborty ${ }^{4}$

\section{HOW TO CITE THIS ARTICLE:}

Jayanta Ray, Abhijit Datta, Ashis Kumar Rakshit, Salil Bindu Chakraborty. "Vulvar Lipoma in Postmenopausal Lady: A Rare Case Report". Journal of Evolution of Medical and Dental Sciences 2014; Vol. 3, Issue 28, July 14; Page: 7792-7794, DOI: $10.14260 /$ jemds/2014/2973

INTRODUCTION: Different lesions may present as vulvar swelling. Bartholin cyst is the most common among different mass lesions of vulva. To mention other mass lesions of vulva are mucous cyst, haemangioma, sebaceous cyst, fibroma, fibromyoma and lipoma. Though lipoma is the most common soft tissue benign tumour of the body, it is very rare in vulva. In post-menopausal lady lipoma of vulva is not reported yet.

CASE REPORT: Sixty years old post-menopausal lady presented in Gynecology OPD with a complaint of that her genitalia is changing into male genitalia. She attained her menopause 15years back. Apparently she was alright till 3years back when a swelling started to grow gradually in her right labia majora and over the time achieved the size of an adult testis. She was depressed and also suffering from hypertension and did not have any other problem. Ultrasound of the swelling suggested a reniform $4.5 \mathrm{x} 3.5 \mathrm{cms}$ soft tissue mass without any increase in vascularity. Fine needle aspiration cytology (FNAC) from the swelling showed lymphoid cells and fibroblastic cells. Excision of the swelling done under Spinal anesthesia and the excised mass was sent for Histopathological examination which confirmed encapsulated $4.5 \times 2.5 \mathrm{cms}$ mass composed of mature adipocytes.

DISCUSSION: Lipomas are the most common soft tissue tumour of the body. ${ }^{1}$ Though lipomas can occur at any age, they are commonly seen in third and fourth decade of life. ${ }^{2}$ These tumors are slow growing benign mass arising from fatty tissue. These soft lobulated masses are encapsulated by thin fibrous tissue. Upper back, neck are the common sites for these tumours. Lipomas of vulva are very rare. So far there 16 cases of vulvar lipomas reported in worldwide literature. ${ }^{3}$ In 2011 two cases of vulvar lipomas were reported within six months gap. ${ }^{4}$

Vulvar lipomas are reported so far in the age group of 5months to 52years. This case report is the only one which is in postmenopausal age of 60years. It is observed that almost all the vulvar lipomas reported so far, are in right labia majora and this case is no exception, but the etiology of vulvar lipoma is not known. Some researcher tried to link trauma to vulvar lipoma. Though exact etiology of vulvar lipoma is still remain uncertain. Association with gene rearrangements of chromosome 12 has been established in cases of solitary lipomas, that has an abnormality in HMGA2LPP fusion gene. ${ }^{5}$ Complete surgical excision with the capsule is advocated to prevent future recurrence of lipoma

CONCLUSION: Vulvar lipoma is very rare. Majority cases reported are in pediatric and adults before attaining menopause. This case of vulvar lipoma probably the first case reported in Postmenopausal age group. Surgical excision is simple and recover was uneventful. 


\section{CASE REPORT}

\section{REFERENCES:}

1. Kehagias DT, Smyrniotis VE, Karvounis EE, Gouliamos AD, Creatsas G. Large lipoma of vulva. Eur J Obstet Gynecol Reprod Biol. 1999 May; 84 (1): 5-6.

2. Basel Khreisat MD, Ahmad Uraiqat MD; Vulvar lipomas: a case report: JRMS june 2012; 19(2): 79-81

3. Maciel Jozwik, Malgorzata Kolodziejczak, Ewa klonowska Dziatkiewicz, Marcin Jozwik; Giant vulvar lipomas in an adolescent girl, a case study and review:

http://www.jpagonline.org/article/S1083-31881(13)00286-6/abstract cited on 27th June 2014.

4. A T Odoi, A Owusu Bempah, E.T. Dassah, D.E. Darkey, S. E. Quayson: Vulvar Lipoma: Is it so rare? Ghana Med J. Sep 2011; 46 (3): 125-127.

5. Italiano A, Ebran N, Attias R, et al. NFIB rearrangement in superficial retroperitoneal and colonic lipomas with aberrations involving chromosome band 9p22. Genes Chromosomes Cancer 2008; 47 (11): 971-7.

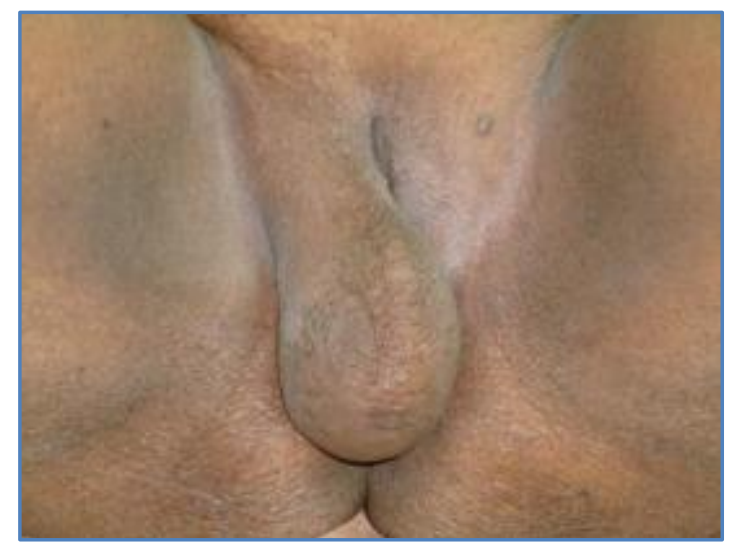

\section{Vulvar Lipoma}

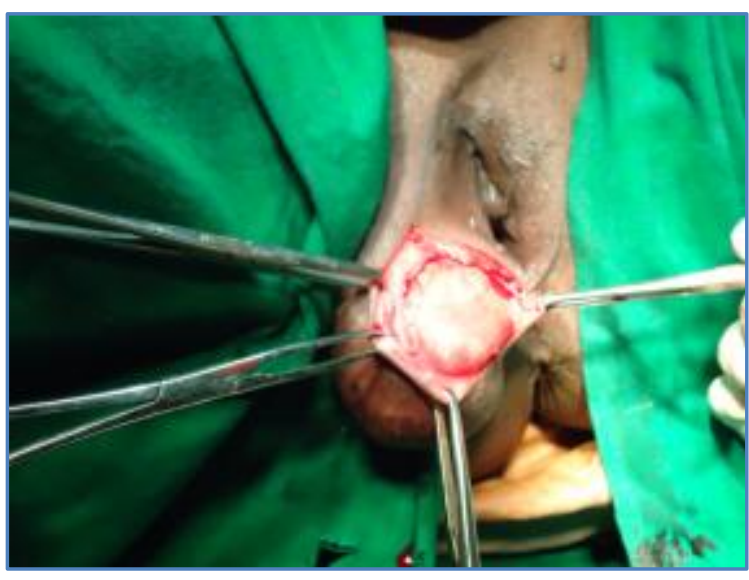

Vulvar Lipoma 


\section{AUTHORS:}

1. Jayanta Ray

2. Abhijit Datta

3. Ashis Kumar Rakshit

4. Salil Bindu Chakraborty

\section{PARTICULARS OF CONTRIBUTORS:}

1. Associate Professor, Department of Obstetrics and Gynaecology, Agartala Government Medical College, Kunjaban, Agartala, Tripura.

2. Associate Professor, Department of Pathology, Agartala Government Medical College, Kunjaban, Agartala, Tripura.

3. Assistant Professor, Department of Obstetrics and Gynaecology, Agartala Government Medical College, Kunjaban, Agartala, Tripura.
4. Assistant Professor, Department of Obstetrics and Gynaecology, Agartala Government Medical College, Kunjaban, Agartala, Tripura.

\section{NAME ADDRESS EMAIL ID OF THE CORRESPONDING AUTHOR:}

Dr. Jayanta Ray,

Palace Compound,

Thakur Anil Krishna Sarani,

Agartala-799001, Tripura.

Email: drjayantray@gmail.com

Date of Submission: 26/06/2014.

Date of Peer Review: 30/06/2014.

Date of Acceptance: 07/07/2014.

Date of Publishing: 11/07/2014. 